\title{
Regional Economic Growth and Air Transportation in Indonesia especially outside Java: a Backward Method in Multiple Regression Model
}

\author{
Byna Kameswara ${ }^{1}$, Tia Adelia Suryani
}

Received: $11^{\text {th }}$ April 2020

Accepted: $10^{\text {th }}$ July 2020

\begin{abstract}
In sustainable development, infrastructure has an important role, although infrastructure growth and investment have positive and negative impacts. Indonesia has a strategic program in the form of infrastructure improvement. However, due to the condition of Indonesia which is an archipelago, infrastructure development has only concentrated on Java, especially in Jakarta City. This resulted in a gap in infrastructure development outside of Java. This study identifies the relationship between infrastructure and the regional economy in Indonesia. Indonesia is an archipelagic country so that long-distance transportation, such as using airports, is an absolute necessity to support equitable economic activities and support sustainable development. The relationship between traffic on airports and regional economies is still debating and growing. Therefore, by looking at the characteristics of the archipelagic country, it is interesting to see the relationship between infrastructure and the regional economy in Indonesia. This research aims to provide an understanding of the effect of economic growth in airports and be able to be a stakeholder consideration to making policies about air transportation and regional economic growth evenly on island geography conditions such as Indonesia. The relationship between the two in this study is shown by looking at traffic in airports and 17 economic sectors of GRDP in six different regencies with similar characteristics. The model show the relationship in this study. This model built using a regression approach. The results of this model show the relationship between traffic in airports with regional economic sectors, especially outside the island of Java. The results of this study can be concluded that the effect is found between the economic sectors of the region on the existence of airports.
\end{abstract}

Keywords: regional economics, regression model, air transportation, sustainable economy

\section{INTRODUCTION}

Debate on the impact and influence of infrastructure development and investment in regional economic growth has taken place since the 1980s. Where experts debate the positive and negative impacts of infrastructure development and investment as part of sustainable development. Infrastructure development and investment had a positive influence and impact on economic growth (Button et al., 2010; Button \& Taylor, 2000; Jin \& Rafferty, 2017; Silva et al., 2016). In addition, regional economic growth was also related to air network changes (Inkinen \& Pyyhtiä, 2013; Matsumoto \& Domae, 2018). Fedderke \& Bogetic (2006) \& Kyriacou et al., (2019) also explained that the relationship between economic growth and infrastructure investment was not free from controversy. In his research (Fedderke \& Bogetic, 2006), the positive impacts and effects were found only on the long-run economic growth in South Africa. The intended impact also includes the role

\footnotetext{
${ }^{1}$ Infrastructure and Mobility Research Group, Faculty of Civil Engineering and Planning, Institut Teknologi Nasional Bandung
}

Correspondence: Kameswara.byna@itenas.ac.id; tiadelia@itenas.ac.id 
of the infrastructure itself. These impacts were also subdivided into direct and indirect impacts. According to Halpern \& Bråthen (2011) the direct impact of investment and infrastructure development was the creation of jobs directly due to construction activities, and the indirect impact is other employment caused by the development. Infrastructure and economic relations were also divided into two, namely direct and indirect relationships (McCarthy \& Zhai, 2019), which were factors of cost (cost) into direct impacts and factors of labor (Bråthen \& Halpern, 2012), capital \& intermediate goods being indirect impacts. Saheed \& Iluno (2015), in his research, also stated that there is an influence of air transportation service activities on economic growth (Khan et al., 2017), the long-term relationship between them, and the indirect relationship between air transportation and economic growth. There was a direct relationship between air transportation services and the urban structure or urban hierarchy (Fernandes et al., 2019). Also, Neuwirth et al., (1993), in his research, tried to understand how the increase in quantity and quality of airport capacity affects the regional economy. Many studies have shown airport services to have a positive impact on regional economic growth. However, it did not indicate that there is a two-way relationship between airport services and economics (Allroggen \& Malina, 2014). For example, population growth affected the improvement of the regional economy, which at the same time, the population also affected the conditions of air transportation services (al Chalabi, 1998).

Connected to the situation in Indonesia, the development of transportation infrastructure in the next few years is the flagship program of the Indonesian Government. The Government of Indonesia aims to have a positive impact, as indicated by the improvement of the regional economic conditions that are equitable. According to data from the Ministry of Transportation of the Republic of Indonesia, Indonesia had 298 airports spread throughout the region. Also, the air transportation sector in Indonesia continues to grow. The number of air transportation passengers increased from $62.4-82.4$ (in millions) from 2011 to 2015. However, it is different from Indonesia's economic growth, which experienced a decline from 2011 - 2015, from $6.5 \%$ to $4.8 \%$. The condition of an archipelago, such as Indonesia, made a concentration of growth on the island of Java, given the country's capital as the center of activity is on the island of Java, the city of Jakarta. Areas outside the island of Java showed different conditions, which had imbalances in terms of development. Even in some countries, the Government as the public transport authority, carries out policy support to the air transportation sector in relation to competition with other parties on the grounds of economic development of public companies (Merkert \& O'Fee, 2013). Therefore, this study aims to understand the relationship between the movement of air transportation services at the airport and regional economic growth, especially sectoral economies in Indonesia, especially outside Java.

Exploratory analysis conducted in this study focuses on build multiple regression models to show the relationship and the value of the influence of economic sectors on traffic at airports in Indonesia, especially outside Java. This research aims to describe there is an influence of regional economic growth on the existence of air transportation in this case airports , and which sectors affect airport traffic with remote area characteristics such as Kalimantan and Java. In contrast to Tveter's research which focused on the short-term effect of construction on employment (Tveter, 2017) and Cattaneo whose research focused on the influence on the local economy development (Cattaneo et al., 2018), this research has a macroscope by looking at regional economic variables. Besides, the direction of the relationship in this study also shows the one-way relationship of regional economic growth to airport data traffic in contrast to Fernandes's research which looked at the opposite relationship (Fernandes et al., 2019) and Baker's research which showed the two-way relationship of these variables (Baker et al., 2015). In the next section, this study will report 
the general condition of airports and regional economics in several regions in Indonesia outside Java Island.

\section{METHODS}

Researchers have developed various statistical models in various contexts to illustrate the indirect relationship of airports on economic growth. These methods such as short-run Granger non-causality analysis (Mukkala \& Tervo, 2013), vector error correction modeling (Forecasting, 2006), Dynamic panel data modeling (Sellner \& Nagl, 2010), 2stage least square regression modeling (Green, 2007), and regression modeling (Blonigen \& Cristea, 2012). in this study, the author uses a multivariate regression model approach using the backward method to understand the relationship between economics and airport activity.

\section{Data}

This study analyzes six airports in six regencies in Indonesia outside Java. These six airports have the same classification based on the service hierarchy, namely as feeders. The six airports and districts are H. Asan-Sampit Airport in East Kotawaringin Regency, Dr. F. L. Tobing in Central Tapanuli Regency, Cut Nyak Dien Airport in Nagan Raya Regency, Nanga Pinoh Airport in Melawi Regency, Datah Dawai Airport in West Kutai Regency, and Depati Parbo Airport in Kerinci Regency. The six districts are in over two large islands in Indonesia, namely Sumatra Island and Kalimantan Island. Where three regencies are in Sumatra Island, and three regencies are in Kalimantan Island. The two islands are also two large islands that are directly adjacent to Java Island as a growth center, as indicated by the presence of the State Capital on Java Island, the Jakarta Metropolitan Area. This airport traffic data is supported by data on the traffic of arrivals and departures services (TOTPW) between 2013 - 2017. This airport traffic data is open access data from official data of the Indonesian Ministry of Transportation

Furthermore, this study analyzes the traffic relationship shown by TOTPW with 17 economic sectors contained in the Gross Regional Domestic Product (GRDP) in the same period of 2013-2017. The secondary GRDP data is obtained from open access data that is owned by all regency cities in Indonesia through the Central Statistics Agency/Badan Pusat Statistik of each Regency City. The seventeen sectors include Agriculture, Forestry, and Fisheries (ES01), Mining and Quarrying (ES02), Processing Industry (ES03), Electricity and Gas Procurement (ES04), Water Supply, Waste Management, Waste and Recycling (ES05), Construction (ES06), Wholesale and Retail; Car and Motorcycle Repair (ES07), Transportation and Warehousing (ES08), Provision of Accommodation and Food and Beverage (ES09), Information and Communication (ES10), Financial Services (ES11), Real Estate (ES12), Corporate Services (ES13), Government Administration, Defense and Mandatory Social Security (ES14), Educational Services (ES15), Health Services and Social Activities (ES16), and Other Services (ES17).

\section{Methodology}

The analysis method used in this study is multiple linear regression analysis as an effort to see the relationship or causality of the specified variable. Multiple regression analysis is used to predict how far the change in the value of the dependent variable if the value of the independent variable is manipulated (Sugiyono, 2010). Therefore the results of the regression analysis model can be used to make decisions on the intervention of independent variables to influence the value of the desired dependent variable. To find out whether the regression model can be used or not in further analysis, a linearity test and a significance test, including a simultaneous and partial test are needed. 


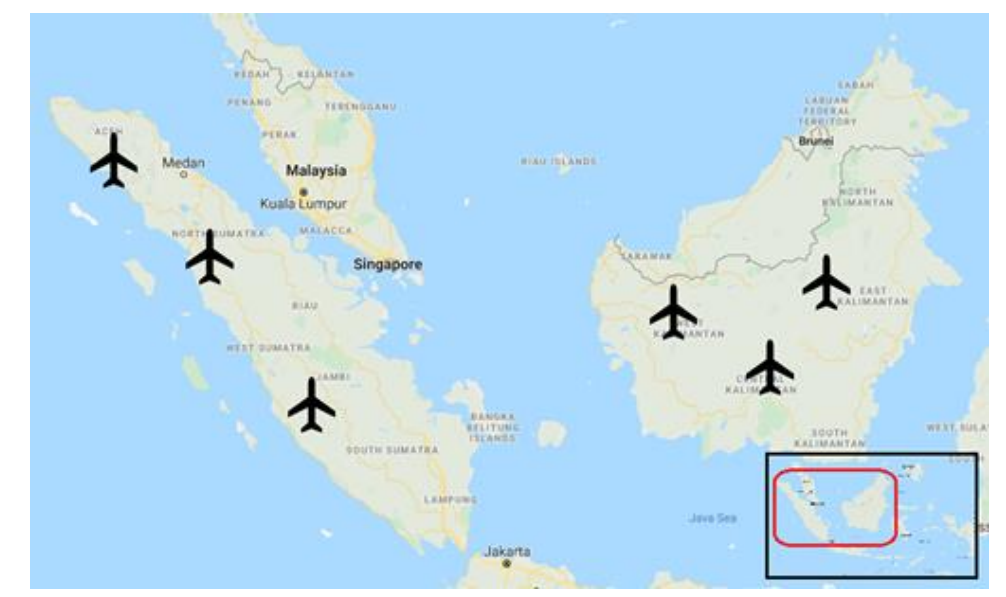

Source: Processed Data, 2019

Figure 1. The distribution of airports as research objects

If there is one dependent variable $(\mathrm{Y})$ of $\mathrm{p}$ independent variables $(\mathrm{X} 1, \mathrm{X} 2, \ldots \mathrm{Xp})$, then multiple linear regression models can be written as follows.

$$
\begin{gathered}
Y=\beta_{0}+\beta_{1} X_{1}+\beta_{2} X_{2}+\cdots+\beta_{p} X_{p}+\varepsilon \\
\boldsymbol{Y}=\boldsymbol{X} \boldsymbol{\beta}+\boldsymbol{\varepsilon}
\end{gathered}
$$

Where,

$\mathrm{Y}=$ dependent variable $(\mathrm{n} \times 1)$

$\mathrm{X}=$ the matrix of independent variable $(\mathrm{n} \times(\mathrm{p}+1))$

$\beta=$ vector of regression model parameters $((p+1) \times 1)$

$$
\varepsilon=\text { vector of error }(\mathrm{n} \times 1)
$$

$$
Y=\left[\begin{array}{c}
y_{1} \\
y_{2} \\
\vdots \\
y_{n}
\end{array}\right] \quad X=\left[\begin{array}{rrrr}
1 & x_{11} & \ldots & x_{1 p} \\
1 & x_{21} & \ldots & x_{2 p} \\
\vdots & \vdots & \ddots & \vdots \\
1 & x_{n 1} & \ldots & x_{n p}
\end{array}\right] \quad \boldsymbol{\beta}=\left[\begin{array}{c}
\beta_{0} \\
\beta_{1} \\
\vdots \\
\beta_{p}
\end{array}\right] \quad \boldsymbol{\varepsilon}=\left[\begin{array}{c}
\varepsilon_{1} \\
\varepsilon_{2} \\
\vdots \\
\varepsilon_{n}
\end{array}\right]
$$

The $\beta$ parameter is estimated to obtain the regression model; here is the formula to estimate the parameter:

$$
\widehat{\beta}=\left(X^{T} X\right)^{-1} X^{T} Y
$$

In the build of the multiple regression model, a Back-ward method is also used to understand any independent variables related to the dependent variable. So the results of multiple regression models can explain what economic sectors that are associated with traffic at the airport significantly and eliminate the independent variables that are not significantly related.

\section{Regional Economy \& Air Transportation}

\section{Regional Economy}

The six regencies that were the object of this study were selected based on the main conditions, the presence of the airports outside Java that have the same hierarchy as feeders. The economic conditions of the regions in each district are different. In 17 existing sectors, several sectors dominate. These sectors differ from one another. East 
Kotawaringin Regency is dominated by three main sectors namely ES01, ES03, and ES07. Second, Central Tapanuli, Kerinci, and Nagan Raya districts are dominated by the ES01 sector. Furthermore, Melawi Regency is dominated by the ES01 and ES07 sectors. Finally, the ES02 sector dominates the economy of West Kutai.

Data from these economic sectors shows that regions outside Java, such as Sumatra and Kalimantan, have diverse economic conditions. The dominant economic sectors in each district, if reviewed, are the primary economic sectors that are the source of regional economic supply chains. This relates to the condition of developing countries in general, where secondary and tertiary sectors dominate Java as a growth center in Indonesia. In contrast to economic conditions outside Java, which is still very dependent on economic development in the primary sector. The differences in the conditions of development and regional development, especially the economic sector outside Java, are very different from one another.

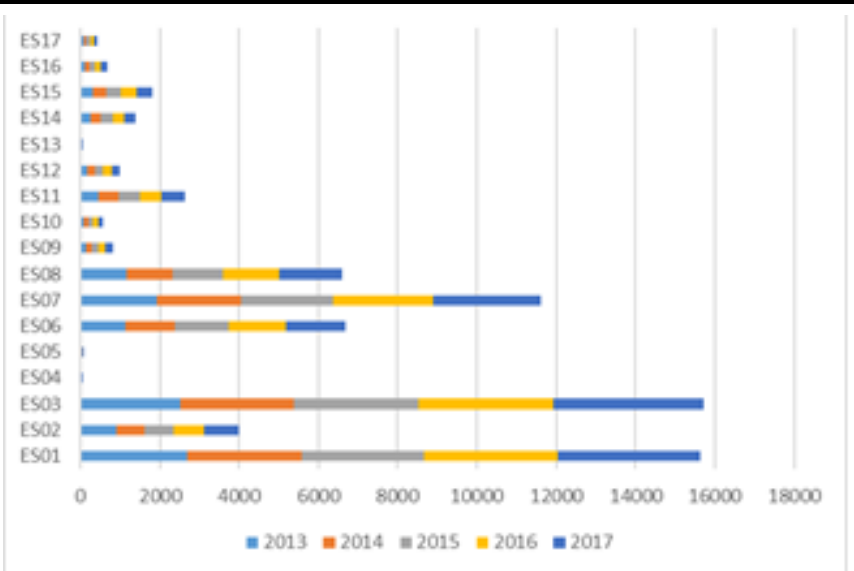

Source: Processed Data of Air Traffic Open Access Data, Ministry of Transportation, Republic of Indonesia, 2019

Figure 2. Kotawaringin Timur's Economic Sector by The Year

Source: Processed Data of Air Traffic Open Access Data, Ministry of Transportation, Republic of Indonesia, 2019

Figure 3. Tapanuli Tengah's Economic Sector by The Year 


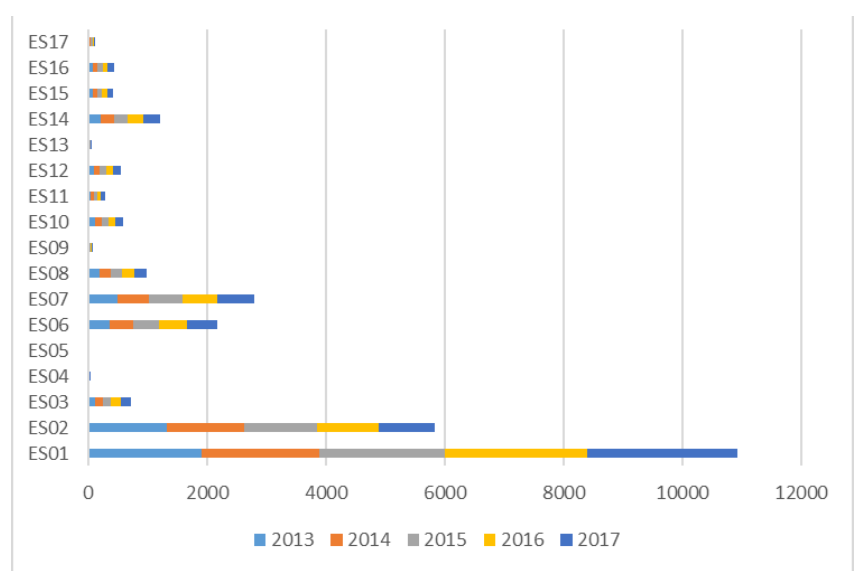

Source: Processed Data of Air Traffic Open Access Data, Ministry of Transportation, Republic of Indonesia, 2019

Figure 4. Nagan Raya's Economic Sector by The Year

Source: Processed Data of Air Traffic Open Access Data, Ministry of Transportation, Republic of Indonesia, 2019

Figure 5. Melawi's Economic Sector by The Year

\section{Air Transportation}

The condition can be seen from the data with airports in the same hierarchy. H. AsanSampit Airport and Dr. F. L. Tobing Airport have higher traffic compared to others, whereas Nanga Pinoh Airport and Depati Parbo Airport fall into the low criteria for airport traffic conditions. Although at the same hierarchy as the feeder airport, it has different traffic conditions at airports in each district. Of the six airports that were the object of this study, only two airports showed an increase in the period 2013 - 2017. Four other airports even experienced a decline. 


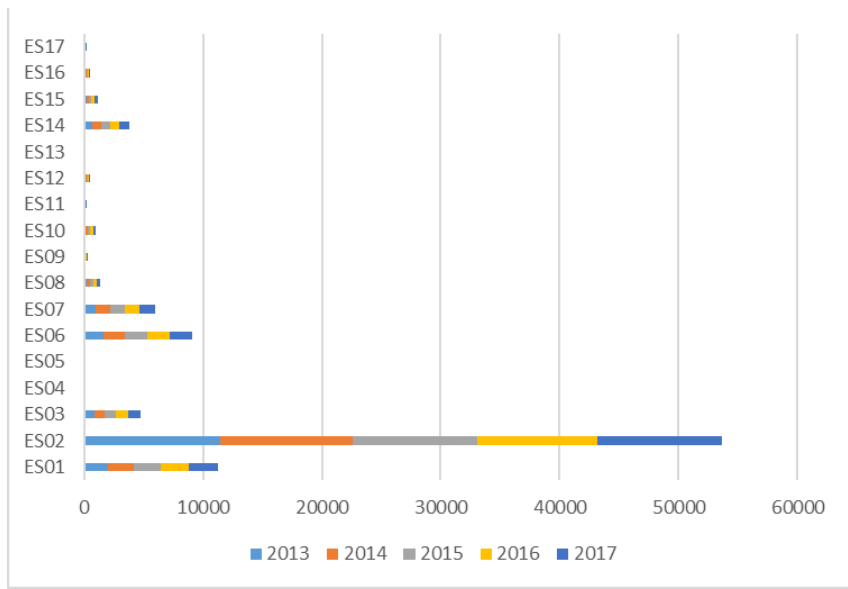

Source: Processed Data of Air Traffic Open Access Data, Ministry of Transportation, Republic of Indonesia, 2019

Figure 6. Kutai Barat's Economic Sector by The Year

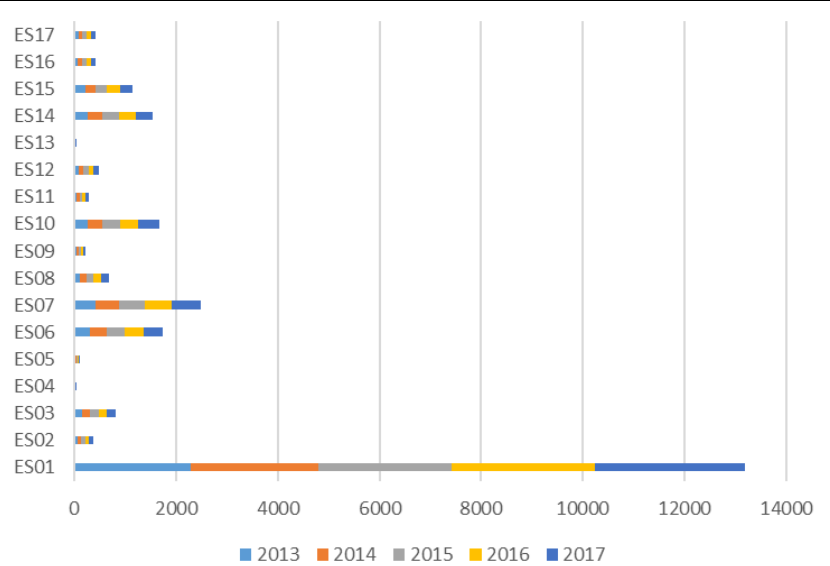

Source: Processed Data of Air Traffic Open Access Data, Ministry of Transportation, Republic of Indonesia, 2019

Figure 7. Kerinci's economic sector by the year

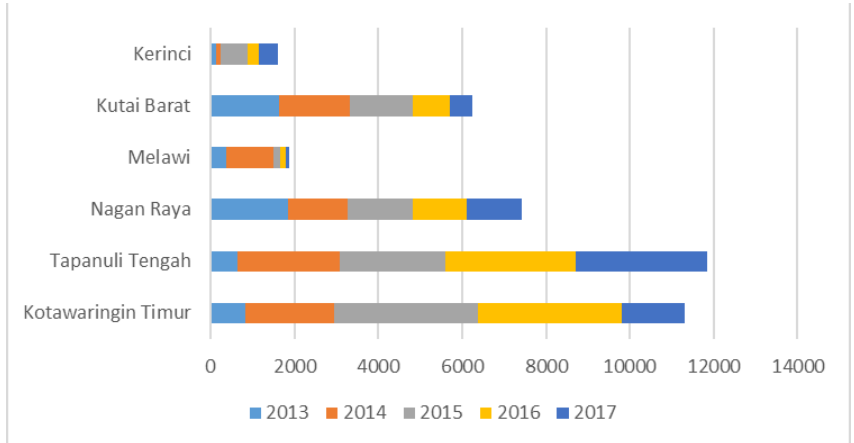

Source: Processed Data of Air Traffic Open Access Data, Ministry of Transportation, Republic of Indonesia, 2019

Figure 8. Airport Traffic by Year 
Table I. Data Normality Test

One-Sample Kolmogorov-Smirnov Test

$\mathrm{N}$

Normal Parametersa,b

Most Extreme Differences

Kolmogorov-Smirnov Z

Asymp. Sig. (2-tailed)

a. Test distribution is Normal.

b. Calculated from data.
Unstandardized Residual

30

0,000

0,200

0,142

0,142

$-0,081$

0,776

0,584

Source: Processed Data, 2019

\section{RESULT}

Before starting the process of constructing a regression model, this study conducts a normality test of the data already collected that is shown in TABLE I.

Based on the results of the normality test, it can be concluded that the data are normally distributed. This is indicated by the significant value that exceeds $0.05,0.58$, so that the process of building a regression model can be continued to the next step.

In the process build a regression model, this study uses the Back-ward method to include each variable in the model. This back-ward method will enter 17 independent variables, namely GRDP, simultaneously and proceed by eliminating one by one variable that has no significant relationship with the dependent variable TOTPW.

Table 2. Coefficient and A Partial Test

\begin{tabular}{llllll}
\hline Model & \multicolumn{2}{l}{ Unstandardized Coefficients } & t & Sig. \\
& & B & Std. Error & & \\
\hline 1 & (Constant) & -3.619 & 2.135 & -1.695 & 0,103 \\
& ES02 & $-0,381$ & 0,168 & -2.265 & 0,033 \\
& ES03 & -2.658 & 0,749 & -3.547 & 0,002 \\
& ES06 & 2.303 & 0,736 & 3.128 & 0,005 \\
& ES07 & 3.963 & 1.081 & 3.665 & 0,001 \\
& ES10 & -1.561 & 0,245 & -6.367 & 0 \\
\hline
\end{tabular}

a Dependent Variable: TOTPW

Source: Processed Data, 2019

Of the 17 independent variables, namely GRDP, five variables made it into the model after passing through the back-ward method in the process of constructing the regression model. The variables include ES02, ES03, ES06, ES07, and ES10. In other words, 12 other independent variables were eliminated from the process of build a multiple regression model. The five selected independent variables partially have an influence on the dependent variable seen from the significant value in TABLE I. It shows that the mining sector, the processing industry sector, the construction sector, the wholesale and retail trade sector, and the information and communication sector have an influence on traffic on airports in conditions separate from one another.

After looking at the partial conditions, simultaneous tests were also carried out on the model, and it shows that the five independent variables simultaneously affected the dependent variable in the regression model that was constructed, which was seen in TABLE II. F value of more than 2.6 ( $\mathrm{F}$ table) means simultaneous, which is 14.057. 
Table 3. Anova And Simultaneous Test

\begin{tabular}{|c|c|c|c|c|c|c|}
\hline Model & & $\begin{array}{l}\text { Sum of } \\
\text { Squares }\end{array}$ & $\mathrm{df}$ & Mean Square & $\mathrm{F}$ & Sig. \\
\hline \multirow[t]{3}{*}{1} & Regression & 4.931 & 5 & .986 & 14.057 & $.000 \mathrm{~b}$ \\
\hline & Residual & 1.684 & 24 & .070 & & \\
\hline & Total & 6.615 & 29 & & & \\
\hline
\end{tabular}

Source: Processed Data, 2019

Table 4. Test Of Determination

\begin{tabular}{lllll}
\multicolumn{1}{l}{ Model Summary } & & \\
\hline Model & $\mathrm{R}$ & R Square & Adjusted R Square & Std. Error of the Estimate \\
1 & $.863 \mathrm{a}$ & .745 & .692 & .264889 \\
\hline
\end{tabular}

a Predictors: (Constant), ES10, ES07, ES02, ES06, ES03

b Dependent Variable: TOTPW

Source: Processed Data, 2019

The multiple regression model that build also underwent a determination test. The results of the determination test are seen in the $\mathrm{R}$ Square value, namely the independent variable in the regression model can explain the model by $75 \%$ while there are still $25 \%$ of the independent variables that do not enter the model development process. Finally, the resulting multiple regression model is as follows,

$$
Y=-3.619-0,381(E S 02)-2.658(E S 03)+2.303(E S 06)+3.963(E S 07)-1.561(E S 10)
$$

The results of the construction of the regression model also show economic sectors; in this case, any independent variables that affect the dependent variable, namely airport traffic outside Java Island in Indonesia. It appears that three independent variables are inversely proportional to the dependent variable, and two independent variables are directly proportional to the dependent variable.

\section{DISCUSSIONS}

The condition of the archipelago, such as Indonesia, presents different challenges in the development and economic development of the region (Fröhlich \& Niemeier, 2011; Wijaya \& Furqan, 2018). Equitable development is an essential factor in pushing each region on the separate islands of the big and small islands. Therefore, a fair and specific distribution of infrastructure also contributes to improving the economic conditions of a region. So it can be concluded that infrastructure, in this case, is shown by the traffic at the airport that has a relationship with economic growth in archipelagic countries such as Indonesia.

Air transportation is an essential part besides sea transportation in the condition of an island nation like Indonesia. This condition shows a high demand for people and goods mobility by air and sea. Baker et al., (2015) shows the classification of the relationship between air transportation services and the regional economy. Other regions besides Java Island as a growth center have different regional conditions in terms of economy and air transportation. Primary economic sectors, such as agriculture and mining, become the primary sectors that encourage economic growth outside Java. Nevertheless, the role of the economic sector in the presence of airports the results are not significant. A positive relationship was found in the economic sector of construction and wholesale trade \& retail, 
which fall into the category of secondary and tertiary economic sectors. It is interesting to know further; there is a direct relationship or an indirect relationship between the two sectors.

The effect is found between the economic sectors of the region on the existence of airports. The role of economic sectors in Indonesia still influences the existence of airports (Graham \& others, 1995). This study also found that not all sectors have a significant relationship to traffic at airports. This is similar to some previous studies (Brocker, 2005; Quinet \& Vickerman, 2004). Also, the time-series data used in this study shows that the influence of the mining sector, the processing industry sector, the construction sector, the wholesale and retail trade sector, and the information and communication sector have a short-term impact on airport traffic outside Java Island. However, it needs further study related to how the level of competition affects the economic conditions of the region, such as research by Merkert \& Mangia, 2014.

\section{CONCLUSIONS}

The results of this study can be concluded that the effect is found between the economic sectors of the region on the existence of airports. Otherwise, not all sectors have a significant relationship with airport traffic. The mining sector, the manufacturing sector, the construction sector, the wholesale and retail trade sector, and the information and communication sector have a short-term impact on airport traffic outside Java.

\section{ACKNOWLEDGEMENT}

The authors would like to thank the Bandung National Institute of Technology / Institut Teknologi Nasional Bandung in terms of funding our research so that this research can be completed and also The Ministries of Transportation and Statistical Centers/Badan Pusat Statistik in each district in providing data.

\section{REFERENCES}

al Chalabi, M. (1998). The impact of a major commercial airport on urban development: A case in Chicago. Ekistics, 65(388-390), 131.

Allroggen, F., \& Malina, R. (2014). Journal of Air Transport Management Do the regional growth effects of air transport differ among airports ? Journal of Air Transport Management, 37, 1-4. https://doi.org/10.1016/j.jairtraman.2013.11.007

Baker, D., Merkert, R., \& Kamruzzaman, M. (2015). Regional aviation and economic growth: cointegration and causality analysis in Australia. Journal of Transport Geography, 43, 140-150. https://doi.org/10.1016/j.jtrangeo.2015.02.001

Blonigen, B. A., \& Cristea, A. D. (2012). Airline Traffic and Regional Growth: Evidence from a Major Policy Experiment.

Bråthen, S., \& Halpern, N. (2012). Air transport service provision and management strategies to improve the economic benefits for remote regions. Research in Transportation Business \& Management, 4, 3-12.

Brocker, J. (2005). Principles of Transport Economics. Journal of Economic Geography, 5(2), 257-259. https://doi.org/10.1093/jnlecg/lbh065

Button, K., Doh, S., \& Yuan, J. (2010). The role of small airports in economic development. Journal of Airport Management, 4(2), 125-136.

Button, K., \& Taylor, S. (2000). International air transportation and economic development. Journal of Air Transport Management, 6(4), 209-222.

Cattaneo, M., Malighetti, P., \& Percoco, M. (2018). The impact of intercontinental air accessibility on local economies: Evidence from the de-hubbing of malpensa airport. Transport Policy, 61(January 2017), 96105. https://doi.org/10.1016/j.tranpol.2017.10.009

Fedderke, J. W., \& Bogetic, Z. (2006). Infrastructure And Growth In South Africa : Direct And Indirect Productivity Impacts Of 19 Infrastructure Measures. The World Bank. https://doi.org/10.1596/18139450-3989

Fernandes, V. A., Pacheco, R. R., Fernandes, E., \& Ribeiro, W. (2019). Regional change in the hierarchy of Brazilian airports 2007 - 2016. Journal of Transport Geography, 79(March), 102467. 
https://doi.org/10.1016/j.jtrangeo.2019.102467

Forecasting, O. E. (2006). The economic contribution of the aviation industry in the UK. London, UK.

Fröhlich, K., \& Niemeier, H.-M. (2011). The importance of spatial economics for assessing airport competition. Journal of Air Transport Management, 17(1), 44-48.

Graham, B., \& others. (1995). Geography and air transport. John Wiley \& Sons. https://www.cabdirect.org/cabdirect/abstract/19961801798

Green, R. K. (2007). Airports and economic development. Real Estate Economics, 35(1), 91-112.

Halpern, N., \& Bråthen, S. (2011). Impact of airports on regional accessibility and social development. Journal of Transport Geography, 19(6), 1145-1154. https://doi.org/10.1016/j.jtrangeo.2010.11.006

Inkinen, T., \& Pyyhtiä, M. (2013). Geographical specialization and connectivity of air passenger flows from Northern Europe to Asia and US. Asian Geographer, 30(2), 87-104.

Jin, J., \& Rafferty, P. (2017). Does congestion negatively affect income growth and employment growth? Empirical evidence from US metropolitan regions. Transport Policy, 55, 1-8.

Khan, S. A. R., Qianli, D., SongBo, W., Zaman, K., \& Zhang, Y. (2017). Travel and tourism competitiveness index: The impact of air transportation, railways transportation, travel and transport services on international inbound and outbound tourism. Journal of Air Transport Management, 58, 125-134.

Kyriacou, A. P., Muinelo-Gallo, L., \& Roca-Sagalés, O. (2019). The efficiency of transport infrastructure investment and the role of government quality: An empirical analysis. Transport Policy, 74, 93-102.

Matsumoto, H., \& Domae, K. (2018). The effects of new international airports and air-freight integrator's hubs on the mobility of cities in urban hierarchies: A case study in East and Southeast Asia. Journal of Air Transport Management, 71, 160-166.

McCarthy, P., \& Zhai, Z. (2019). Economic impact analysis of GDOT short line railroad infrastructure investment in Georgia. Research in Transportation Economics, 77, 100728.

Merkert, R., \& Mangia, L. (2014). Efficiency of Italian and Norwegian airports: a matter of management or of the level of competition in remote regions? Transportation Research Part A: Policy and Practice, 62, 3038.

Merkert, R., \& O’Fee, B. (2013). Efficient procurement of public air services-Lessons learned from European transport authorities' perspectives. Transport Policy, 29, 118-125.

Mukkala, K., \& Tervo, H. (2013). Air transportation and regional growth: which way does the causality run? Environment and Planning A, 45(6), 1508-1520.

Neuwirth, R. M., Reed, J. S., \& Weisbrod, G. E. (1993). Airport area economic development model. PTRC International Transport Conference, Manchester, England.

Quinet, E., \& Vickerman, R. W. (2004). Principles of transport economics. Northampton, MA.

Saheed, A. A. A., \& Iluno, S. Z. C. (2015). Air transportation development and economic growth in Nigeria. Journal of Economics and Sustainable Development, 6(2), 1-11.

Sellner, R., \& Nagl, P. (2010). Air accessibility and growth--The economic effects of a capacity expansion at Vienna International Airport. Journal of Air Transport Management, 16(6), 325-329.

Silva, G. J. C. da, Martins, H. E. de P., \& Neder, H. D. (2016). Investimentos em infraestrutura de transportes e desigualdades regionais no Brasil: uma análise dos impactos do Programa de Aceleração do Crescimento (PAC). Brazilian Journal of Political Economy, 36(4), 840-863.

Sugiyono, D. (2010). Metode penelitian kuantitatif kualitatif dan R\&D. xiii.

Tveter, E. (2017). The effect of airports on regional development: Evidence from the construction of regional airports in Norway. Research in Transportation Economics, 63, 50-58. https://doi.org/10.1016/j.retrec.2017.07.001

Wijaya, N., \& Furqan, A. (2018). Coastal tourism and climate-related disasters in an archipelago country of Indonesia: tourists' perspective. Procedia Engineering, 212, 535-542. 